УДК 069.8 (477)

DOI: $10.33099 / 2707-1383-2020-38-4-196-203$

Тугай M.I., молодший науковий співробітник, Філія НВІМ України - Музей «Герої Дніпра»

(м. Івано-Франківськ, Україна)

ORCID: https://orcid.org/0000-0001-5540-2953

\title{
МУЗЕЙНІ ПРЕДМЕТИ АТО-ООС ТА ЇХ ЕКСПОНУВАННЯ У МУЗЕЇ «ГЕРОЇ ДНІПРА»
}

\begin{abstract}
У статті проаналізовано науково-дослідну та музейно-експозиційну роботу наукових співробітників Музею «Герої Дніпра» — філії Національного військово-історичного музею України, присвячених пам'яті учасників Неоголошеної війни. У науковій роботі науковиі Музею здійснюють дослідження у відповідній проблематииі, публікують наукові розвідки та статті, а також результати своїх досліджень апробовують на міжнародних науково-практичних конференціях. Фахівиями Музею «Герої Дніпра» здійснено відповідну музейно-експозиційну роботу у напряму зібрання відповідних колекцій присвячених подіям АТО-ООС. Зазначено, щзо основну увагу при утворенні відповідних виставок та експозицій приділено військовослужбовиям із Івано-Франківської області.
\end{abstract}

Ключові слова:експозичія, колекиія, АТО-ООС, музей «Герої Дніпра», публікації.

Постановка проблеми. Бойові дії на Сході України є одними з драматичніших подій у новітній історії України. Неоголошена війна, яка триває з 2014 р., викликає інтерес не тільки у політичних і військових осіб, а також всіх громадян України. Сторінки бойової слави учасників Антитерористичної операції - Операції об'єднаних сил (АТО-ООС) $є$ назавжди закарбовані у пам'яті людей. Події неоголошеної війни привертають увагу у великого спектру науковців різних галузей та спеціальностей: історії, психології, географії, фізики, хімії та інших прикладних та гуманітарних дисциплін. У збереженні пам'яті про ці події, а також поширення знань у широкі маси населення, одне з чільних місць належить музейним установам. Зокрема, дана проблематика має широке висвітлення у науково-дослідній та музейно-експозиційній роботі музею «Герої Дніпра» (м. Івано-Франківськ).
Мета статті - на основі виявлених та зібраних музейних матеріалів та експонатів, розкрити науково-дослідну та музейно-експозиційну діяльність наукових співробітників Музею «Герої Дніпра», спрямовану на висвітлення історії бойових дій на Сході України.

Виклад основного матеріалу. Науково-дослідна та музейно-експозиційна робота наукових співробітників Музею «Герої Дніпра» базується на дослідженні сторінок українського війська від часів Київської Русі до сучасного етапу формування Збройних Сил України. Чільне місце у роботі співробітників музею займає напрацювання наукових матеріалів а також збільшення колекції та виставок присвячених подіям на Сході України.

Фахівцями музею проводиться грунтовна наукова робота стосовно висвітлення окремих сторінок з історії подій на Сході України. Зокрема, опубліковано праці, що 
присвячені однієї з героїчних сторінок сучасного Українського війська - оборони Донецького аеропорту [3], а також у одній iз публікацій зазначено список із загиблими оборонцями Донецького аеропорту, які є уродженцями Івано-Франківської області [4].

Наукові співробітники Музею «Герої Дніпра» приймали участь у підготовці та редагуванні фундаментальної книги, присвяченій пам'яті військо службовців, які загинули за суверенітет, територіальну цілісність та недоторканість України.

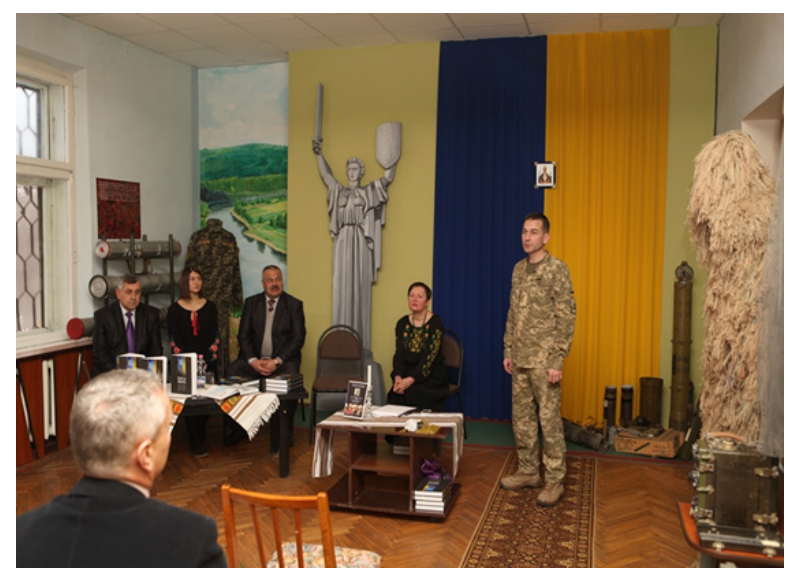

Puc. 1. Презентація другого тому «Книги пам’яті»

Безпосередньо, у Музеї «Герої Дніпра» за участі науковців, представників громадськості та родичів загиблих на Сході України 20 грудня 2017 р. відбулась презентація (рис. 1) другого тому «Книга пам'яті військослужбовців Збройних Сил України, які загинули, захищаючи суверенітет, територіальну цілісність та недоторканість України» (Книга II: Автономна Республіка Крим, Запорізька, Івано-Франківська, Київська, Кіровоградська, Луганська і Львівська області та місто Київ) [5]. Завідувач філії НВІМ України Музею «Герої Дніпра» Я. Кваснюк наголосив, що цю книгу написали своїми життями ті люди, історії яких на її сторінках [7].
Констатуємо, що науковими співробітниками Музею «Герої Дніпра» продовжує здійснюватися відповідна наукова робота. Фахівцями розширюється тематика досліджень, відбувається співпраця із іншими музейними та науковими установами.

Окремою сторінкою роботи наукових співробітників Музею є створення відповідних колекцій, у якій зберігаються предмети 3 місць бойових дій, особисті речі та спорядження військових а також зразки стрілецької зброї, боєприпасів різних форм та калібрів і засоби зв'язку.

Чільне місце в експозиції Музею «Герої Дніпра» займає розділ «Збройні сили України на захисті суверенітету, територіальної цілісності і недоторканності держави» [6]. У нього входять окремі, менші експозиції, зразки та макети сучасного озброєння, особисті речі військовослужбовців а також різні осколки від снарядів.

Найбільшою виставкою 3 даної експозиції у Музеї «Герої Дніпра» є виставка «Неоголошена війна Україні» (рис. 2), яка висвітлює події на сході країни через призму участі в ній прикарпатських бійців [6]. У даній експозиції відтворено героїчні факти із фронтового життя непересічних уродженців Прикарпаття, додано поіменний список загиблих воїнів області.

Цінним експонатом даної виставки є саморобний Державний прапор України, привезений полковником Ю. В. Верановським 3 Мар'янки, в зоні проведення АТО, де він висів над військовим шпиталем. Урочисто переданий ним особисто до Музею під час відкриття виставки «Неоголошена війна Україні» 16 серпня 2016 р.

Дану експозицію доповнюють особисті речі прикарпатських військовослужбовців, як приймали участь у бойових діях на Сході України. Зокрема, В. Веляником, який служив у 17-у окремому мотопіхотному батальйоні 67-ї мотопіхотної бригади, 


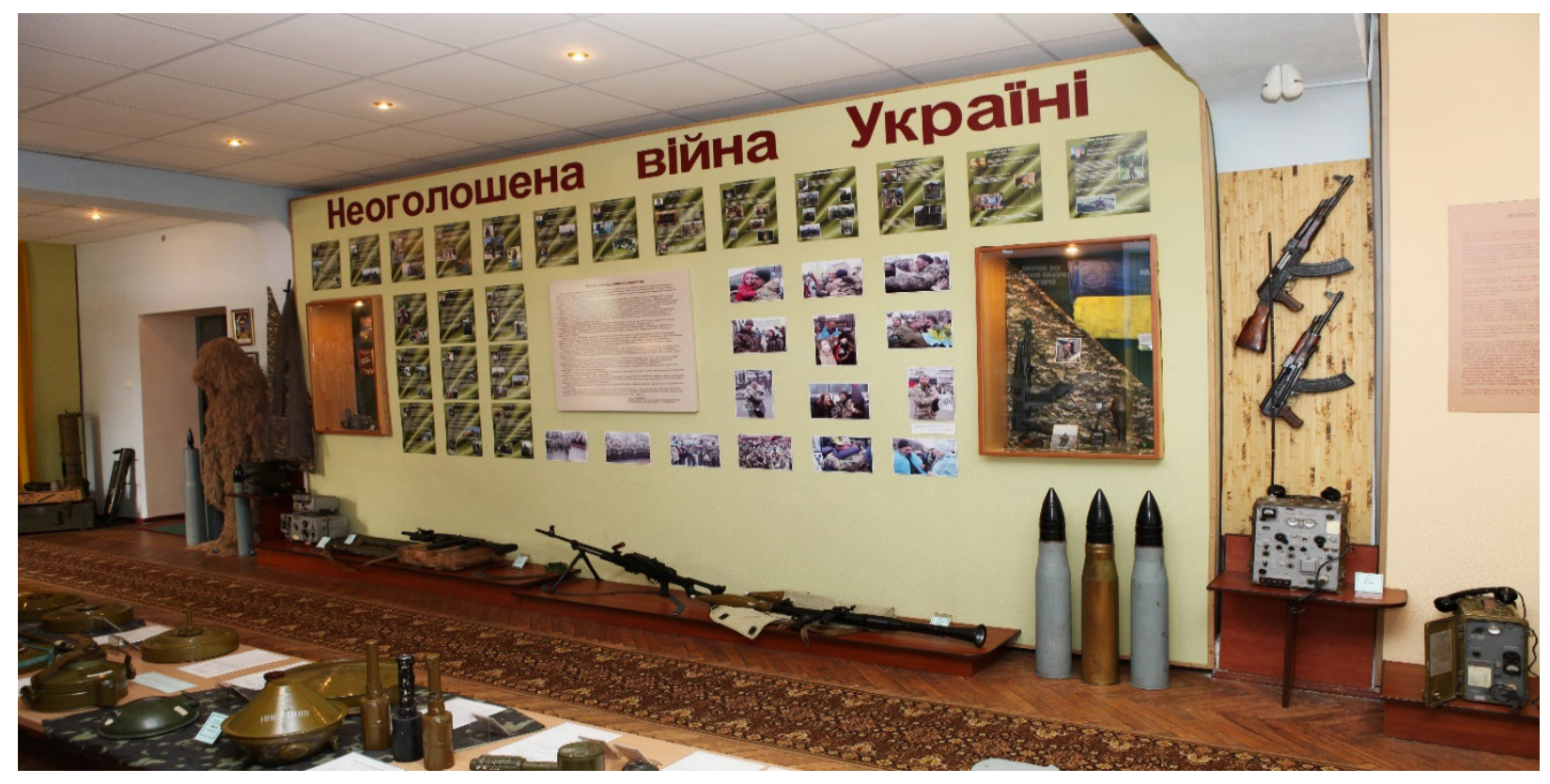

Puс. 2. Виставка «Неоголошена війна Україні»

було передано власний шеврон, кулі різного калібру, деактивовануміну 82 мм, на якій розміщені підписи його побратимів, муляжі гранат. Старший розвідник О. Талімонов передав у Музей особистий жетон. Учасник бойових дій на Сході України, колишній співробітник Музею «Герої Дніпра» М. Вуянко подарував у музей рацію.

Матір'ю загиблого добровольця, снайпера Національної гвардії Р. Юрчишина Марією Іванівною у Музей передано його портрет а також вишита молитва бісером. Експонується подарунок українським воякам на Сході України, виготовлений в техніціоригамі учнями ЗОШ № 15 під керівництвом вчительки Кузьмак Лесі Михайлівної. На виставці представлений снайперський камуфляж «Кікімора», який виготовили спеціально для виставки у Музею Івано-Франківські майстрині 3 розплетених мішків, аналогічний тому, які вони плетуть для наших військових.

Особливою $\epsilon$ виставка «Перерваний політ» (рис. 3), створена на вшанування пам'яті загиблому екіпажу гелікоптеру Mi-8МТ (16 «жовтий»), який було збито терористами 29 травня 2014 р. поблизу м. Слов'янська. Центральним експонатом даної експозиції $є$ особистий кітель полковника у роки служби у Івано-Франківській області, генерал-майора С. Кульчицького. Вказаний кітель у фонд Музею передала особисто вдова покійного Н. Кульчицька. Окрім цього представлено життєвий та бойовий шлях генерал-майоpa. Слід зазначити, що окрім С. Кульчицького у гелікоптері загинуло ще дванадцять осіб, серед яких шість прикарпатців, співробітників спеціальної роти міліції УМВС України в Івано-Франківській області: прапорщик міліції В. Лисинчук, старші лейтенанти П. Безпалько та В. Семанюк, старшина міліції П. Остапюк, старший сержант міліції В. Яковяк, старший прапорщик В. Шарабуряк [5]. Про них усіх підготовлений та виставлений на показ матеріал біографічного характеру а також їх фотографії. Планується доповнити виставку їх особистими речами. 


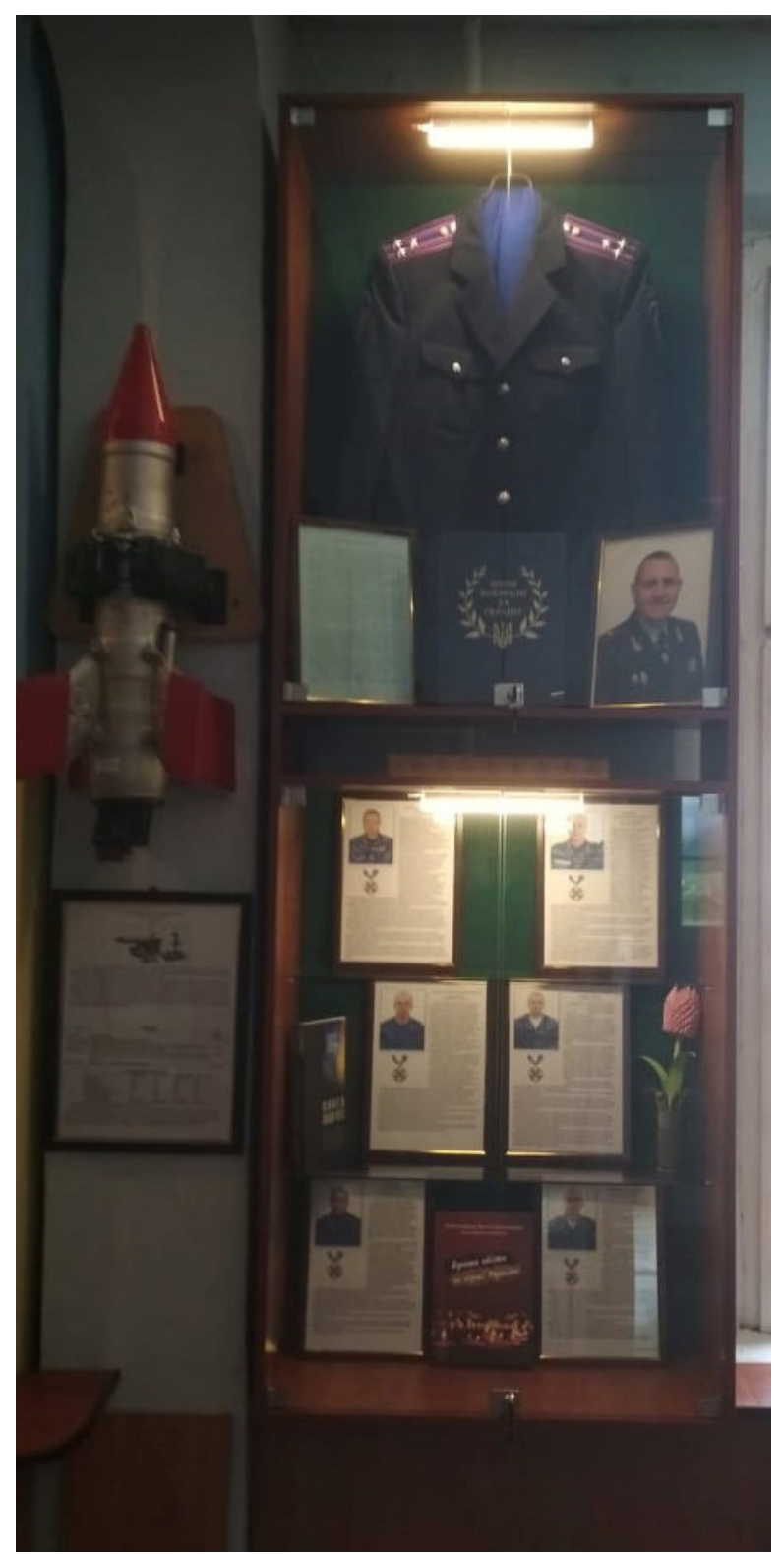

Рис. 3. Вітрина генерал-майора С. Кульчицького

Серед експонатів Музею «Герої Дніпра», які відображають події на Сході Україні $\epsilon$ осколки і залишки різного озброєння ATO-OОС (рис. 4). Цінністю цих експонатів в тому, що вони показують відвідувачам Музею наслідки обстрілів для військових та цивільного населення прифронтових територій. Це осколки і залишки озброєння реактивних систем залпового вогню («Град», «Ураган» та інші), залишки розбитого військового спорядження та боєприпасів тощо.

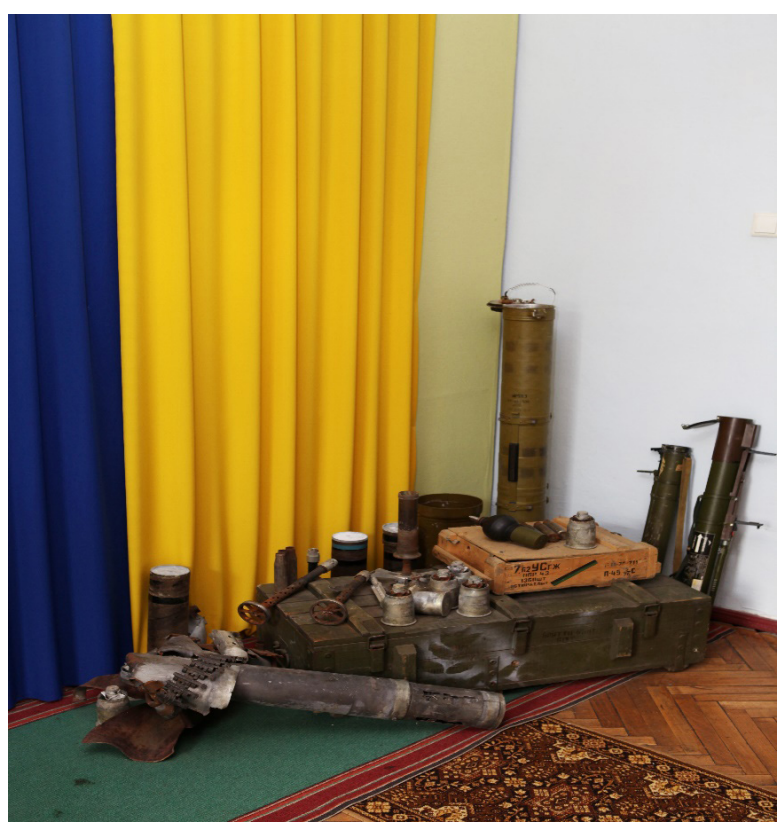

Pис. 4. Осколки і залишки озброєння iз зони АТО-ОOC

Доповнює експозицію багата колекція зразків стрілецької зброї, якою користуються наші військовослужбовці. Зокрема, автоматичний гранатомет АГС-17 «Полум'я», реактивний протитанковий гранатомет РПГ-22 «Нетто», ручна реактивна граната (гранатомет) РПГ-18 «Муха», 40-мм ручний протитанковий гранатомет РПГ-7, станковий протитанковий гранатомет СПГ9 «Спис», 5,45-мм автомат Калашникова АК-74 3 підствольним гранатометом ГП25, 5,45-мм ручний кулемет Калашникова РПК-74 та інше озброєння а також ручна кумулятивна граната РКГ-3. Дані експонати наочно показують озброєння, яким користуються українські військовослужбовці.

Окрім різноманітних зразків стрілецької зброї у Музею «Герої Дніпра» є колекція інженерних боєприпасів. Усі вони використовуються у бойових діях на різних ділянках фронту неоголошеної війни. Безпосередньо, це різні протитанкові, протипіхотні та інші різновиди мін. На узбережжі Азовського моря українські військові використовують протидесантні міни ПДМ- 
$1 \mathrm{M}$, вони призначені для знищення малих десантних пливучих засобів і техніки, протитанкова міна ТМД-40, протитанкова міна TM-57 та інші.

У експозиції Музею «Герої Дніпра» представлені макети сучасних реакційних систем залпового вогню різного калібру. Зокрема, це 227 мм БМ-27 «Ураган», 122 мм БМ-21 «Град» та інші.

До уваги відвідувачів Музею представлені стенди 3 історії бойового шляху окремих військових бригад, які базуються на території Івано-франківської області та Карпатського регіону. Так, відвідувачі Музею можуть ознайомитись із історією 114ої бригади тактичної авіації, яка базується у м. Івано-Франківську. Представники бригади брали участь при виконанні завдань у зоні АТО у складі 25-ої та 95-ої окремих аеромобільних бригад, 72-ої окремої механізованої бригади, інших частин Збройних Сил України. У м. Коломия (Івано-Франківська область) базується 10-та окрема гірсько-штурмова бригада, сформована 30 жовтня 2015 р. головним завданням якої $\epsilon$ ведення бойових дій у гірсько-лісистій місцевості. Основною метою створення бригади є захист від гіпотетичних територіальних претензій на північну Буковину 3 боку Румунії. Можна ознайомитись 3 історією 128-ї окремої гірсько-піхотної бригади. Основне місце іiї дислокації м. Мукачеве (Закарпатська область). Від початку війни на Сході України бійці 128-ї бригади зайняли місця в Луганській області, в районі Лисичанська, Сєвєродонецька та Рубіжного. Останній стенд із історією військових бригад висвітлює історію 24-ї окремої механізованої бригади, місцем дислокації якої є м. Яворів (Львівська область). Бійці даної бригади спільно з тактичними групами були задіяні у звільненні Слов'янська, Красного Лиману і Краматорська. Всі вказані бригади а також інші з честю та гідністю виконують завдання в рамках проведення АТО-ООС на Сході України.

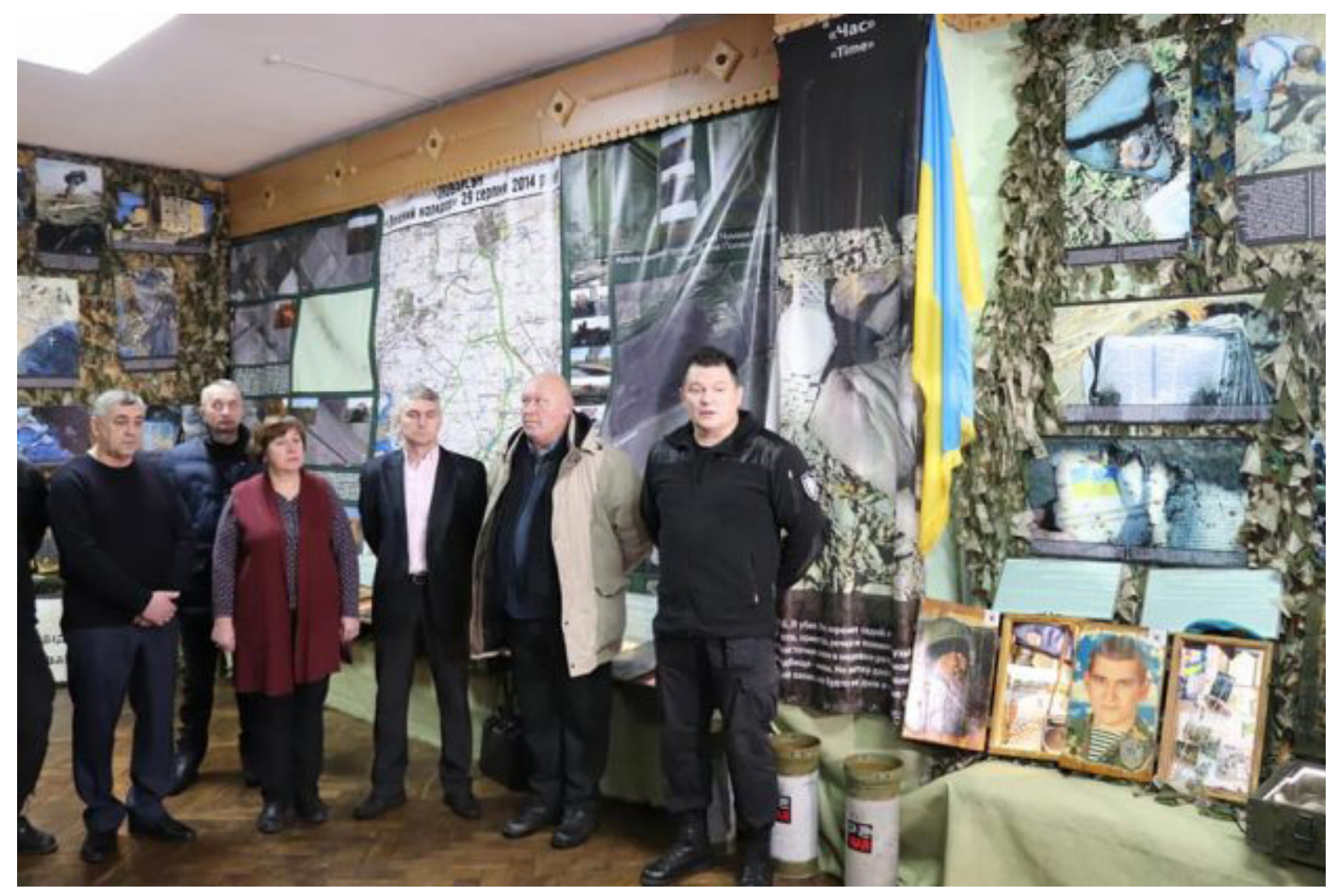

Рuс 5. Виставка «Блокпост памяті» 
Відвідувачі Музею «Герої Дніпра»протягом кількох днів січня 2019 р. мали змогу ознайомитись із пересувною виставкою «Блокпост пам'яті» (рuс. 5), яка тривалий час «мандрує» по Україні. 3 нею вже познайомились мешканці Одеси, Миколаєва, Львова та інших міст України. На ній представлено експонати із зони бойових дій ATO-ООС [2]: зіпсовані шоломи та бронежилети, понівечений одяг, фотоілюстрації, ікони, різноманітні документи, годинники, телефони та ще багато різних предметів. Збором та організацією даної виставки займались військові, волонтери, представники пошукових груп «Чорний тюльпан», «Евакуація 200», союз «Народна пам'ять» та Міжнародна асоціація дослідників фортифікацій «Цитадель» [1]. Завдяки їм, дану виставку можуть побачити та ознайомитись в усіх містах України.

Слід зазначити, що науковими співробітниками Музею «Герої Дніпра» продовжується зібрання відповідних предметів для їх залучення у розширенні відповідної тематичної експозиції.

Висновки. Науковими співробітниками філії НBIM України Музей «Герої
Дніпра» здійснюється фахова науково-дослідна та музейно-експозиційна робота. Одним із напрямів цієї діяльності є наукове дослідження та розширення музейних експонатів, присвячених подіям на Сході України (АТО-ООС). Науково-дослідна робота фахівців Музею показана у наукових розвідках та статтях науковців, а також безпосередня участь та обговорення у міжнародних науково-практичних конференціях у яких висвітлюються питання пов'язан із трагічними сторінками бойових дій на Сході України. Музейно-експозиційна робота наукових співробітників характеризується зібранням відповідних колекцій, результатом яких $є$ утворення тематичних експозицій та виставок, зокрема «Неоголошена війна». У експозиції Музею наявні цінні експонати, зокрема, різноманітна стрілецька зброя, макети різноманітного тяжкого озброєння, особисті речі українських військовослужбовців та інше. Науковими співробітниками Музею «Герої Дніпра» продовжується відповідна науково-дослідна та музейно-експозиційна робота задля збільшення тематичної колекції та експозиції.

\section{СПИСОК ВИКОРИСТАНИХ ДЖЕРЕЛ ТА ЛІТЕРАТУРИ}

1. «Блокпост на Прикарпатті» // Армія FM. [Електрон. ресурс]. - Режим доступу: https:// www.armyfm.com.ua/blokpost-na-prikarpatt\%D1\%96/

2. Виставка «Блокпост пам'яті»// Бліц-інфо. [Електрон. ресурс]. - Режим доступу : https://www.blitz.if.ua/news/vystavka-blokpost-pam-yati1.html

3. Кваснюк Я. Оборонці Донецького аеропорту // Галицький кореспондент. - 2019. № 4. - 24 січня. - С. 11.

4. Кваснюк Я. Уродженці Івано-Франківщини оборонці Донецького Аеропорту // Збірник матеріалів IV Всеукраїнської наукової військово-історичної конференції «ВІЙНА НА ДОНБАСІ. 2014 - 2018 рр. м. Київ, 11 квітня 2019 року. -С. 219-25.

5. Книга пам'яті військо службовців Збройних Сил України, які загинули, захищаючи суверенітет, територіальну цілісність та недоторканість України (Книга II: Автономна Республіка Крим, Запорізька, Івано-Франківська, Київська, Кіровоградська, Луганська 
і Львівська області та місто Київ) / Національний військово-історичний музей України. К.: Лат \& K, 2017. — 448 c.

6. Музей «Героїв Дніпра» // Офіційний сайт НВІМ України. [Електрон. ресурс]. - Режим доступу: http://nvimu.com.ua/filii/index/3

7. Презентація другого тому «Книги пам’яті військовослужбовців Збройних сил України» у філії НВІМУ - Музеї «Герої Дніпра» (м. Івано-Франківськ) // Офіційний сайт НВIМ України. [Електрон. ресурс]. — Режим доступу:http://nvimu.com.ua/novyny/view_news/137

\section{REFERENCES}

1. «Blokpost na Prykarpatti» // Armiia FM. [Elektron. resurs]. - Rezhymdostupu: https:// www.armyfm.com.ua/blokpost-na-prikarpatt\%D1\%96/

2. Vystavka «Blokpostpamiati»// Blits-info. [Elektron. resurs]. — Rezhymdostupu : https:// www.blitz.if.ua/news/vystavka-blokpost-pam-yatil.html

3. KvasniukYa. OborontsiDonetskohoaeroportu // Halytskyikorespondent. — 2019. — № 4. 24 sichnia. - S. 11.

4. Kvasniuk Ya. Urodzhentsi Ivano-Frankivshchyny oborontsi Donetskoho Aeroportu // Zbirnykmaterialiv IV Vseukrainskoinaukovoiviiskovo-istorychnoikonferentsii «VIINA NA DONBASI. 2014 - 2018 rr. m. Kyiv, 11 kvitnia 2019 roku. — S. 219-225.

5. Knyha pamiati viiskosluzhbovtsiv Zbroinykh Syl Ukrainy, yaki zahynuly, zakhyshchaiuchy suverenitet, terytorialnu tsilisnist ta nedotorkanist Ukrainy (Knyha II: Avtonomna Respublika Krym, Zaporizka, Ivano-Frankivska, Kyivska, Kirovohradska, Luhanska i LvivskaoblastitamistoKyiv) / Natsionalnyiviiskovo-istorychnyimuzeiUkrainy. — K.: Lat\& K, 2017. — 448 s.

6. Muzei «HeroivDnipra» // Ofitsiinyisait NVIM Ukrainy. [Elektron. resurs]. _ Rezhymdostupu: http://nvimu.com.ua/filii/index/3

7. Prezentatsiia druhoho tomu «Knyhy pamiati viiskovosluzhbovtsiv Zbroinykh Syl Ukrainy» u filii NVIMU - Muzei «HeroiDnipra» (m. Ivano-Frankivsk) // Ofitsiinyisait NVIM Ukrainy. [Elektron. resurs]. — Rezhymdostupu: http://nvimu.com.ua/novyny/view_news/137 
Tugai M.I., research Assistant,

National Military-History

Museum of Ukraine Museum

"Heroes of the Dnieper"

ORCID: https://orcid.org/0000-0001-5540-2953

\section{ACTIVITIES OF THE MUSEUM WITHIN THE FRAMEWORK OF COLLECTION OF MUSEUM OBJECTS OF ATO-OOS AND THEIR EXHIBITION IN THE BRANCH OF NMHM UKRAINE OF THE MUSEUM "HEROES OF THE DNIPRO"}

The purpose of the article is to study and characterize the collections of the branch of the National Military History Museum of Ukraine Museum "Heroes of the Dnieper" dedicated to the memory of the participants of the Undeclared War, as well as analysis of research work of the Museum staff in covering the participation of Carpathian Strength. The methodological basis of the study is an interdisciplinary approach. Methods of philosophical and general scientific character are used. For the first time, the collections of the branch of NMHM of Ukraine Museum "Heroes of the Dnieper" were described, as well as the scientific work of the Museum's specialists on the coverage and display of objects related to hostilities in eastern Ukraine. In their scientific work, the Museum's scientists carry out research in the relevant field, publish scientific research and articles, as well as testing at international scientific and practical conferences. Specialists of the Museum "Heroes of the Dnieper" carried out the relevant museum and exhibition work in the direction of collecting relevant collections dedicated to the events of the ATO-OOS. They present a variety of small arms, engineering equipment, models of weapons of various calibers, personal belongings of Carpathian servicemen, the combat path of individual units of Ukrainian troops. It is concluded that one of the important areas of research and museum-exhibition activities of scientists of the Museum "Heroes of the Dnieper" is the coverage and characterization of events in eastern Ukraine and the creation of appropriate exhibitions.

Keywords: exposition, collection, ATO-OOS, "Heroes of the Dnieper" Museum, publications. 